\title{
Research on Internet Financial Risk Prevention Mechanism
}

\author{
Qian Wu \\ Xi’an Peihua University, Xi’an, Shannxi, 710125
}

Keywords: Internet Financial Risk, Risk Prevention, Financial Development

\begin{abstract}
Based on the theory of emerging platform economics and technology acceptance model, as well as the Internet financial institutions, internet finance users, China faces the problems of trust, security and legal issues of the Internet financial network in the current development of Internet finance. The paper makes empirical study on the risk factors that exist in the Internet financial institutions as well as the main factors affecting the users to use the Internet finance so as to put forward the Internet financial risk prevention mechanism.
\end{abstract}

\section{Introduction}

The development of Internet finance is the general trend of social development and it plays an irreplaceable role in our social life. The Internet has entered millions of households and becomes a part of our life, bringing great convenience to our life and work. Since the nineties of the last century, the rapid development of network information technology, people's consumption patterns have undergone tremendous changes. Network technology to bring convenience to people from another side reflected in the people's financial management. Internet banking, online securities and online investment have been involved in people's lives. In recent years, the popularity of Alipay has brought online banking to a new stage. People use the Internet shopping, financial management, even the most important red envelopes of the New Year can also be paid through the Internet, truly "a designated all" realm. The development of Internet finance brings people convenience as well as risks. There are still some vulnerabilities in cybersecurity and more needs to be done in terms of security to create a safer platform for Internet finance. The existence of these risks have certain influencing factors. In this paper, taking these influencing factors as starting point, we study the prevention mechanism of Internet finance and make some contribution to the development of Internet finance [1].

\section{Internet finance development present situation and problem analysis}

In recent years, with the rapid development of Internet technologies, especially the extensive and in-depth use of information technologies such as cloud computing, social networking, big data and search engines, the rapid rise of emerging formats based on Internet platforms or applications, in which the rise of Internet finance is particularly rapid, and with its unique charm shows a huge market space and development potential [2]. From the perspective of the development of Internet finance, there are the following characteristics: First, on the development momentum, the most important factor for the emergence and development of Internet finance is Internet technology innovation, industrial form evolution, lifestyle change, lag in traditional financial innovation and lack of coverage. On the evolvement of the industry, the penetration of Internet companies into the Internet and the business innovation based on the Internet in the traditional financial industry are the two main lines of development of Internet finance. Thirdly, on the market performance, there are "four aggregates of personnel gathering, science and technology gathering, capital accumulation and risk gathering "phenomenon. Fourthly, from the service mode, Internet finance infiltrated Internet finance in the traditional financial industry with the Internet spirit of "openness, equality, cooperation and sharing", realized the transformation of financial service mode, diversified the financial activities and promoted the development of financial markets More active, improved resource allocation efficiency. 
However, the development of Internet finance faces the following common problems at the same time: First, the current phase of Internet finance is still in a disorderly development stage. The openness of the Internet has, to a certain extent, lowered the access threshold for the financial industry, leaving a large number of Internet companies involved in the financial sector. The number and scale of operations have developed rapidly, but have not been effectively incorporated into the traditional financial management framework. Most of the Internet financial formats are "unmanaged" except for third-party payment. Second, the lack of industry standards. Internet finance belongs to the emerging industries, most of the formats are still lack of authority, a unified industry self-regulatory organizations and industry standards. At present, in addition to the third-party payment agencies already have the authority of the self-regulatory organizations - China Payment and Liquidation Association, and the development of the corresponding industry norms, other such as P2P network lending, crowdfunding and other forms of authority is still lacking associations and industry standards. Third, the social credit system is not perfect. Due to the mixed use of Internet financial companies, taking into consideration the need to protect the personal and corporate credit information security, Internet financial enterprises such as P2P and crowdfunding platforms are still unable to access the PBC credit system. Fourth, the potential financial risks are greater. Internet business philosophy and traditional financial institutions are essentially different. The former places more emphasis on user interaction, entertainment and cross-borderness, while the latter tends to be rigorous and steady. Internet product innovation to the ultimate user experience as the guide, the traditional financial institutions product design to security and stability as the orientation. Internet companies are more open to "cross-border innovation in the cross-border" and "traditional law enforcement can not forbid it," while traditional financial institutions are cautious on such innovations with "law not allowed". Although the Internet financial services launched by some Internet companies can make good use of the rapid growth of the Internet, their long-term development still depends on the operators' professional control of financial risks, the use of the Internet solely for marketing, and institutions lacking good financial professional skills Late risks may be gradually exposed [3].

With the rapid development of science and technology and continuous improvement of network technology, consumers are increasingly using network technology to enrich their own lives and manage and use their own property through the Internet. Internet finance can make consumers full Home will be able to control their own possessions and complete the appropriate trading activities. In the process, some malicious businesses hang the names of formal financial institutions quietly into the lives of consumers. When consumers see these messages, with their trust in the financial institutions and the temptation of some interests, easily fall into the trap of these trash business among them, thus making their own property suffered heavy losses. These businesses use the name of the formal financial institutions to deceive or even steal the property or income of consumers, thus incurring immeasurable losses to consumers. This is also a great risk to Internet finance. Law exists in people's daily life, any person's behavior will be bound by law, financial institutions are no exception. Compared with traditional financial institutions, Internet finance will be subject to more laws, such as the Consumer Protection Law, the Intellectual Property Protection Law, the Personal Privacy Protection Law and the Labor Protection Law. Internet finance will assume a greater risk.

\section{Internet financial risk prevention mechanism}

Unlike traditional payment methods, online payment for internet financial transactions is conducted on the open Internet. Large amounts of data need to be transmitted over the Internet and include sensitive information such as orders, checks, credit card account information, and identification. Once such information is stolen during the Internet transmission, tampering, will affect the normal network payment, and even cause huge losses to users. In order to protect the security of private data in network payment, encryption technology needs to be applied to prevent sensitive information from being acquired externally. The main technical means of security protection for Internet financial transactions is encryption, which is a powerful means to ensure the integrity, availability and confidentiality of Internet financial transaction information. Encryption 
technology can not only effectively applied to digital signatures, but also can protect the safety of stored data in the Internet financial system to prevent electronic fraud, and thus play a key role in the security of internet financial transaction network payment. At the same time, encryption technology is the core technology of Internet financial information security [4].

To ensure the normal operation of the Internet financial system, the Internet financial system must first be able to correctly identify the identity of Internet financial transaction parties and use it as a basis for controlling its trading activities so as to ensure that only legitimate clients can access the Internet financial transaction system. For internet finance clients, be sure to make sure that the servers to which they connect are indeed their target trading servers, rather than the existence of fake, fraudulent trading servers. Therefore, there is a need for two-way identity authentication between Internet financial customers and Internet financial institutions. The authentication technology adopted by internet finance is the main realization technology of network payment security. Internet financial institutions to adopt authentication technology to meet the needs of online payment security, specifically to ensure Internet financial transaction identity authentication, transaction data confidentiality, integrity and non-repudiation. The authentication technology used in Internet finance mainly involves identity authentication, digital certificate and the like. Identification refers to the confirmation of the identity of transaction participants by the Internet financial trading system, so as to effectively prevent risks. In general, Internet financial user authentication, through the following three basic ways or a combination of ways to achieve: password-based identity authentication. Including static password technology (such as user name password technology) and dynamic password technology (such as one-time password technology); Based on physical authentication credentials. That is, users must possess legal physical media such as smart card, USB Key, etc. Biometrics-based authentication. This method identifies the user by examining the physiological or behavioral characteristics of the user. Commonly used biometric authentication methods include face authentication, iris authentication, fingerprint authentication, palm print authentication, voice authentication and the like [5].

In order to safeguard people's freedom and responsibility, we must apply the changes to the big data prediction so that personal privacy protection can change from personal permission to data users' responsibility. From conventional notebooks to digital repositories, a lasting message store. Memory such as Google's digital storage or P2P lending agencies, travel reservation systems, telecom operators and law enforcement has a complete and powerful digital memory. Because large search engines have amassed a large amount of digital memories that are relevant to us, we are in a data circular prison and we are extremely wary of them, which can make our behavior chilling. To ensure that they are judged by considering their personal responsibilities as the basic support for big data management rather than using objective data as a basis for judging whether they are against the law or not. We need to promote the protection of privacy by adopting and promoting new technologies, differentiated privacy. However, the development of big data at the same time, there will be a huge risk, making the current privacy protection methods and core technologies ineffective.

The implementation of our country is based on the credit system led by the Central Bank, which is different from the credit information system dominated by commercial credit agencies in Europe and the United States. At present, Internet banking institutions use the central bank credit information, there are still some difficulties. With the central bank gradually opening up individuals to obtain their own credit reports, basically all Internet financial institutions will require borrowers to print their own reports or authorize the transfer. However, Internet financial institutions can neither directly query nor submit user data. The former increases the time cost for platform to obtain personal credit report, the latter reduces the platform's deterrent effect on the default of the borrower, resulting in the reduction of the cost of default and the increase of the repeated borrowing.

At present, China's commercial credit agencies all share data in the form of membership or cooperation. Specifically, Internet financial institutions must first become members of commercial credit agencies, abide by the data requirements of credit agencies. After reporting the data according 
to the agreement, the Internet financial institutions can conduct personal information data query. Internet financial institutions and commercial credit agencies through cooperation, which can achieve Internet financial industry information sharing. It is a practical way to solve the problem of decentralized credit information and data closure of all platforms by organizing information sharing and forming a local database through commercial credit agencies. Due to the disagreement among contributions of platforms of different scales on Internet financial institutions, there is a problem that the platform is not willing to share data. However, as a basic business credit support, in line with the overall interests of the Internet finance industry. In theory, larger Internet financial platforms, despite their large amounts of data, have matched their own business queries so that there is no issue of imbalances in input-output.

\section{Conclusions}

The risks in Internet finance are the most serious, because what he involves most is the consumer's property and interests. These risks are complicated and varied. The reasons are all due to the development of Internet information technology and the impact of national law. Therefore, in order to guard against these risks, we should start from these two perspectives and establish a sound financial Network system to protect the financial institutions of their own safety; increase legal supervision, from the national point of view to protect Internet finance and consumer interests. With the two-pronged approach, we can truly guard against the risks existing in the Internet finance so as to protect the legitimate rights and interests of consumers and financial institutions more effectively and provide a healthier development environment for Internet finance.

\section{References}

[1] Chen Xiaohui. Third-party payment of precipitation funds and regulatory [J]. Southern Finance, 2007: 34-37.

[2] Chen Lin. Internet finance development and supervision [J]. Southern Finance, 2013,11: 52-56.

[3] Chen Zhiwu. Violent Conflicts in Private Lending and Debt: Debt Mortgages in Qing Dynasty [J]. Journal of Economic Research, 2014,9: 162-175.

[4] Ding Chengcheng, Qiu Jin: "Gender and credit: the micro-individual characteristics of the protagonist of illegal fund-raising - based on the analysis of network data mining", Zhejiang University of Finance and Economics work papers, 2014.

[5] Fan Ruqian, Shi Yuzhou, Ye Qing. Analysis of third party payment money laundering risk and regulatory recommendations [J]. Shanghai Finance, 2008: 46-49. 